\title{
LITHUANIA'S DECLARATION OF INDEPENDENCE: DANISH AND SCANDINAVIAN REACTIONS*
}

\section{BENT JENSEN}

\section{Odense University}

In contemporary Danish political propaganda you often find statements to the effect that relations between Denmark and the Baltic countries have always been very close, based upon a similar outlook on culture, etc. Unfortunately, for the propagandists this is not true. It is, as a matter of fact, a completely false picture as everyone who has only a superficial knowledge of the matter knows. A new Danish historical work concludes that Denmark's policy towards the Baltic countries "in general was one of "wait-and-see". [... Denmark] wanted to have as little to do with these states as possible. Their independence was ... regarded as unstable and Denmark rejected all Baltic efforts to obtain closer political and economic links to Scandinavia'.

In the Soviet period these countries were almost forgotten in Denmark, but even in the period of independence between the two world wars, relations were rather scarce and sometimes strained, certainly never cordial or even friendly. Economic relations were disappointing. Danish government officials tended to view the Baltic nations as immature, inexperienced and difficult to relate to. When the three Baltic countries were occupied and included in the Soviet Union, no official tears were shed and there were no public protests - in stark contrast to official and public Danish reactions to the fate of Finland at the same time. The Danish chargé d'affaires in Kaunas was of the opinion that Lithuania was one of the best proofs of how hopeless it had been with human resources as they were after World War I to establish a series of new and politically immature East

*The following abbreviations are used in this article: FO - Foreign Office (London); FRUS - Foreign Relations of the United States; MG - Ministère de la Guerre (Paris); UM - Udenrigsministeriet (Danish Foreign Office).

'Christian Frederiksen. Danmark og de baltiske lande 1918-1940 (1997, unpublished). 
European states. ${ }^{2}$ Even if Denmark did not formally recognize the Soviet annexation of the Baltic states de jure, it did so de facto. After the annexation, the three Baltic diplomatic missions in Copenhagen were no longer recognized as such and were closed.

Here I shall concentrate upon the reactions in Denmark and, only to a lesser degree, on the reactions in other Scandinavian countries. The pattern of reactions was, however, rather similar in the three countries, because the Scandinavian governments coordinated their policy as far as possible. By 'reactions' I have in mind mainly official reactions, either in the form of internal deliberations or in the form of communications to Lithuanian and other Baltic representatives. My sources are mainly documents from the archive of the Danish Foreign Ministry (now deposited in the Danish State Archive (Rigsarkivet) in Copenhagen. To a lesser degree I have used the contemporary Danish press. I also draw on published historical literature in Denmark and other countries.

Denmark and the Russian Empire: National awakening and economic interests

To understand Danish and Scandinavian reactions to the Baltic nations' declarations of independence, it is necessary to have developments in the Russian Empire in mind and to look at Danish and Scandinavian policies as regards the so-called Russian Question after 1917.

\section{A People Awakening}

For the Danes in general, and the Danish Foreign Ministry in particular, everything from the Baltic Sea to the Pacific Ocean was simply 'Russia' and 'Russian'. The awareness of specific Baltic nations was weak. There were, however, very short entries in the Danish general encyclopedia (Salmonsens Konversationsleksikon) on these nations. ${ }^{3}$ The newly awakened Lithuanian national consciousness is underlined and the Lithuanian journal Auszra (Dawn), published in Tilsit, 1883-1886, is mentioned. Also the fact that most Lithuanian journals and newspapers were published in Prussia and in America because of the policy of Russification and Russian censorship. The article states that in the parts of Lithuania situated in Russia any literary movement is suffocated by the Russian government's prohibition of 1864 against Lithuanian books in Latin letters.

I would, however, like to draw your attention to one remarkable person, a Danish citizen of Icelandic origin, by name Åge Meyer Benedictsen. He was a linguist and writer who took an extraordinary

${ }^{2}$ UM 73 D 34. Worsaa to UM 18.4.1939. UM Politiske depecher. Worsaa to Munch 23.3. og 15.4.1939.

${ }^{3}$ Salmonsens Konversationsleksikon. Copenhagen, 1901. 
interest in suppressed nations and their fight for liberation. As early as 1895 he published a book about Lithuania and Lithuanian history and culture, Et Folk der vaagner. Kulturbilleder fra Litaven (A People Awakening. Descriptions of Lithuanian Culture). In this book, which was also translated into English, Benedictsen wanted to explore the meaning and importance of national feeling. He was deeply convinced that in order to be able to take part in the common world culture one has to be solidly rooted in one's own national culture. $\mathrm{He}$ also thought of the language as 'the fortress of a nation.' He characterized the Lithuanian people at the end of the nineteenth century as 'one of Europe's unhappy peoples.' Once a strong and free people, it was later suppressed and made powerless. But now - in spite of all the prophecies to the opposite - it was awakening. This nation of peasants, he concludes, was realizing that it is a distinct people with its own language and its own country. ${ }^{4}$

In many ways Benedictsen's book reads like a commentary to the situation in the 1980s.

You can also find some very negative Danish attitudes to the Baltic nations. J. Johansen, a landscape engineer by profession, who in 1918 was appointed Danish Consul General in Tallinn was of the opinion that the Estonians were 'a diligent and hard-working peasant people which in no way should be counted among the cultivated'. If Estonians were on a higher level than Russians were it was solely due to healthy German influence. ${ }^{5}$ I should think that his opinion of Lithuanians was of the same sort.

Business Dreams and Expectations

In Danish business circles expectations with regard to Russia ran high in the decades before 1917. Danish industrialists and businessmen, living in a small but well organized and consolidated national state were much occupied by 'the new America', i.e., Russia with Siberia - an unruly empire undergoing rapid industrialization and extensive land reform. According to Danish businessmen, Russia was 'the country of unlimited possibilities, conveniently situated by the same sea as Denmark and presenting itself as a near-by field for Danish initiatives and ventures. Many were dreaming of quickly making a fortune in Russia, others were building castles in the air concerning Copenhagen and its Free Port becoming a world centre for Baltic and Russian Trade.

${ }^{4}$ Åge Meyer Benedictsen. Et Folk der vaagner. Kulturbilleder fra Litaven. Copenhagen, 1895 , passim.

${ }^{5}$ UM 146 D 10. Johansen to UM 26.5.1919. 
These dreams and expectations were reinforced by the intimate dynastic relations between Denmark and Russia. A daughter of the Danish king Christian IX, Dagmar, was married to tsar Alexander III and so became Empress of Russia. Even after tsar Alexander's premature death in 1894 the Dowager Empress retained much of her influence which she used to further Danish economic interests in Russia. Private Danish companies were established in growing numbers in the Russian Empire, many of them in the Western part including the Baltic provinces. To name a few of them: The Great Northern Telegraph Company operated lines of communications across the Eurasian Continent from the Baltic to the Pacific coast. The East Asiatic Company had a steamship company registered in Russia which carried emigrants from the empire to America and ran hotels for would-be emigrants in Liepāja (Libau). Aarhus Oliefabrik had an oil mill for processing linseed in the same Baltic city. The Siberian Company with offices all along the Trans-Siberian Railway exported butter from Siberia in great quantities to Western Europe and America through the ports of Windau and St. Petersburg.

Denmark and the Baltic successor states.

The question of recognition

A Danish rector of the so-called folk high school predicted in 1918 that the Baltic countries would become 'little Denmarks', by which he meant countries adopting the system of the Danish co-operative movement in agriculture-related industries plus the idea of the Folk High School - the ideological or spiritual branch of the co-operative movement. However, just to become little Estonias, Latvias and Lithuanias the new states had to become recognized members of the community of nations. They also had to defend themselves against military onslaughts in co-operation with internal revolutionary forces.

'The Russian Border States'

Successive Danish (and other Scandinavian) governments and also the Danish press, apart from the Communist one, in the period 1917-1921 expected the Bolshevik regime to collapse rather quickly and some sort of 'normal' Russian government to be reestablished and to gain control over the former empire. Danish governments were therefore very reluctant to support or to recognize new states formed on the territory of the former Russian empire. This was also true as regards the 'Russian border states' or 'Baltic fringe states' as they were referred to in Scandinavia.

The Lithuanian National Council (Lietuviu Tautos Taryba) was the first of the three Baltic nations to inform the Danish government of its wish to be recognized as an independent state. In December 1917 the Taryba informed the Danish embassy in Washington of its 
existence, and in February 1918 the Taryba sent a letter from Lausanne to the Foreign Ministry in Copenhagen in which it described itself as 'the Supreme organ of the Lithuanian state and people for Lithuanians in the Fatherland and in the Lithuanian colonies in Russia and America.' The letter referred to a decision taken by the Lithuanian parliament in Vilnius in September 1917 about proclaiming an independent Lithuanian state with Vilnius as its capital. ${ }^{6}$

There was no Danish reaction. A whole year later, in December 1918, Professor Voldemaras informed the Danish Embassy in Berlin that he and a commission consisting of five to six persons would like to go to Denmark in order to negotiate with representatives of the Entente Powers about foreign troops to protect the new state and to discuss its future borders. The Danish government decided to issue a visa to Voldemaras, but it did not want to have the Lithuanian commission in the country. It was told that it could not come to Denmark because of a housing shortage. Voldemaras was received by the Danish Foreign Minister in early 1919 who asked him to present his wishes in writing. This he did a little later. He also addressed himself to the other Scandinavian governments. All three states told him that they would (only) recognize Lithuania de facto. In the meantime, a Lithuanian diplomatic mission had established itself in Copenhagen in 1919. The Danish government was not impressed when told that thanks to Lithuania the Bolshevik threat to Europe had then been stopped. Denmark confirmed its principal position in November 1920 by writing about its readiness to 'maintain de facto relations with the Lithuanian state and its representatives in Denmark' ${ }^{7}$

On 25 February 1918 Konstantin Päts, president of the newly formed Estonian Provisional Government, informed the Danish government of Estonia's declaration of independence passed the day

${ }^{6}$ UM 148 D 10. Lietuvių Tautos Taryba to Danish embassy in Washington December 1917 and to Danish Foreign Ministry 9.2.1918, signed by president, Dr. V. Xovas.

${ }^{7}$ UM 148 D 10. Danish Embassy in Berlin to UM 11,.12.1918; UM to embassy in Berlin 14.12.1918; Lithuanian legation in Denmark to UM 25.10.1920; UM to Lithuanian legation 5.11.1920. A popular Danish journal published a photo of Voldemaras under the headline 'The Baltic Chaos' with the following text: 'The young man in the circle is also a refugee from an unstable corner. He is professor Voldemaras, Prime Minister and provisional regent of Lithuania. He stays in a hotel in Copenhagen, from where he leads the people's republic which has chosen him as its leader. Lithuania, which is also at the moment ravaged by terror, is the hinterland of Courland-Estonia and has a population of nearly 5 million. 
before. In April of the same year an Estonian delegation arrived in Copenhagen to ask for formal recognition, but also in vain.

When the Scandinavian Prime Ministers and Foreign Ministers met in Copenhagen in June 1918 to discuss various problems connected with the war, there was total agreement to continue the policy of 'impartial neutrality' as regards diplomatic relations with, and recognition of, new states emerging from Russia. The Scandinavians also agreed to confer among each other before extending de jure recognition to any of the new governments. ${ }^{8}$

In the meantime a book about contemporary Lithuania was published in Denmark and in Danish in 1919. ${ }^{9}$ The book had been edited by Jurgis Savickis - the Lithuanian de facto representative in Denmark - and contained 11 articles on various questions, among others Åge Meyer Benedictsen's 'Reborn Lithuania', TumasVaižgantas 'The People's Will', Jurgis Alekna 'Our Tasks' and I. Jurkunas-Scheinius 'Lithuanian-Polish Relations'.

Great Power Influence: France

A very influential factor in the Danish reluctance to recognize the new Baltic states was the position of France, which at the time did not want to further the splitting up of the former Russian Empire. Denmark was very dependent on France, one of the victors in the Great War against Germany. Denmark had lost the provinces of Schleswig and Holstein in Prussia's war against Denmark in 1864. With Germany defeated, there was hope of getting at least some of the lost territory back again. And France was instrumental in that respect.

\section{The Right to National Self-Determination}

It did not seem to bother the Danish government that in order to get Denmark's lost provinces back it was appealing to the universal principle of national self-determination for Danes living under German rule in Schleswig and Holstein, but forgetting this same principle for nations at the other shore of the Baltic Sea living under Russian rule.

In 1920 the northern part of Schleswig was reunited with the Danish Kingdom after a referendum was held in the former Danish provinces.

${ }^{8}$ Helene Carlbäck Isotalo. Sweden and Russia in Dissolution 1918-1919. Some political and economic aspects of the Swedish Government policies towards the Baltic Countries, the Ukraine and other new states. The Baltic in International Relations Between the Two World Wars. Studia Baltica Stockholmiensia 3. Stockholm, 1988, 220-221.

${ }^{9}$ Lysskcer. En Samling politiske og фkonomiske Afhandlinger om Litauen. Redigeret og udgivet af Jurgis Savickis. Copenhagen, 1919. 


\section{Great Power Influence: Great Britain}

In October 1918 London wanted Denmark and other Scandinavian states to intervene militarily in support of the new Baltic states which were seriously threatened by Soviet intervention supported by local Bolsheviks. The Danish government was rather well informed about the serious situation in the Baltic area. ${ }^{10} \mathrm{~A}$ British memorandum characterized the Bolshevik threat against the Baltic republics as a general threat against the interests of all civilization. If the Scandinavian governments did not see fit to intervene militarily, Great Britain wanted them to support the new states with military equipment. London promised to refund the expenses. ${ }^{11}$

The Danish foreign minister, Erik Scavenius, promised to carefully study the British memorandum and consult with his Scandinavian colleagues. But he also at once mentioned two factors which would make Danish contribution to a Scandinavian military expedition force very unlikely. One factor was 'possible complications' with the Bolshevik government in Moscow, the other was a refusal to intervene on the part of the 'advanced' political parties in Denmark. By that he meant opposition to any military solution by the two pacifist parties controlling the Danish government at the time, the Radical Left and the Social Democratic parties. ${ }^{12}$

\section{Great Power Influence: Russia and Germany}

In letters of instructions to Danish diplomats Erik Scavenius explained Denmark's position. He thought that military intervention in the Baltic countries by a Danish expeditionary force was 'out of the question.' The same held true for support in the shape of Danish military equipment. He drew attention to the fact that the Danish government already once had discussed a similar matter, i.e., military support to the Finnish government during the civil war in Finland. Opposition from the already mentioned political parties had made such support impossible. He also mentioned the fact that Denmark also had reacted to appeals for military support directly from the Baltic governments by answering that 'efficient support' was not possible.

The Danish Foreign Minister, however, also argued 'foreign policy considerations' at a time when the situation in Russia and in the countries bordering on Germany was so unstable and un-

${ }^{10} \mathrm{UM} 147 \mathrm{E} 4$. Various reports from 1918.

${ }^{11} \mathrm{FO} 3713344$ 177187. British memorandum of 28.10.1928.

${ }^{12}$ FO 3713344 180215. Kilmarnoch to FO 29.10.1918. See also the report to State Department by the American chargé d'affaires in Copenhagen, FRUS. 1918. Russia II (Washington 1931), p. 843-844. 
clear. ${ }^{13}$ By that, apparently, he meant that it could be dangerous for Denmark to be involved in territorial questions where great powers like Russia and Germany had vital interests at stake. At the time Denmark still had an official diplomatic representative in Soviet Russia, Danish Red Cross missions in Petrograd and Moscow, and several Danish citizens in Soviet Russia looking after their big investments. ${ }^{14}$

In a letter of instruction to the Danish ambassador in London Erik Scavenius wrote that the British Government would understand Denmark's refusal. The Danish Workers' Party was against a Danish military contribution. The ambassador was told to inform London that no principal objections lay behind the Danish answer. ${ }^{15}$ At precisely that time there was growing unrest among Danish workers and the Danish government was very nervous, fearing revolutionary actions. ${ }^{16}$

When Sweden also decided - and for the same reasons as Denmark - not to send troops or military equipment to the Baltic countries, the British ambassador in Copenhagen was formally told that it was impossible to send Danish soldiers out of the country and to diminish the stockpiles of weaponry in Denmark. ${ }^{17}$

A few weeks later, however, Denmark agreed to sell 900 Danish produced Madsen machine guns to Great Britain. The weapons were taken to the Baltic area aboard British warships. The Danish government was promised by the British that the Danish machine guns would not be used in an ongoing conflict. But of course everybody knew that they were going to be used against the Bolsheviks. ${ }^{18}$

When the Danish government received alarming appeals from Danish consular representatives in the Baltic area during December 1918 it decided to appoint a special Consul General in Reval to take

${ }^{13}$ UM 147 E 4. Erik Scavenius to the Danish embassies in Kristiania (Oslo) and Stockholm 29.10.1918 and to Danish embassy in Berlin 4.11.1918.

${ }^{14} \mathrm{MG} 7 \mathrm{~N}$ 680. Intelligence report No. 611, 5.11.1918.

${ }^{15}$ UM 147 E 4. Erik Scavenius to Danish embassy in London 5.11.1918.

${ }^{16}$ Bent Jensen. Danmark og det russiske spфrgsmål 1917-1924. Aarhus, 1979, $145 \mathrm{ff}$.

${ }^{17} \mathrm{FO} 211$ 473. Kilmarnock to FO 9.11.1918. See also minutes of 9.11.1918, UM 147 E 4. For more details of Sweden's policy see Seppo Zetterberg. Die schwedische Regierung und die baltische Krise im Herbst 1918, Reval und die baltischen Länder. Festschrift für Helmut Weiss zum 80. Geburtstag. Marburg / Lahn, 1980. 75-89; Helene Carlbäck Isotalo. Sweden and Russia, 224.

${ }^{18}$ FO 3713361 193104. Kilmarnock to FO 30.11.1918. UM 79 D 191. Minutes by Kruse of 1.12.1918 and 18.5.1921. 
care of Danish citizens and Danish economic interests. It also decided to have a Danish warship prepared to go to the area to evacuate Danish citizens if need should be. In the end, however, the British navy took over these tasks. ${ }^{19}$

Copenhagen as a British Naval Base

Denmark, however, supported the British war effort on behalf of the new Baltic states in other ways. When London wanted to use Copenhagen and its harbour facilities after the German capitulation in November 1918, the Danish government agreed. Copenhagen was used as a British base up till 1921 - a rather substantial contribution from an officially neutral country. ${ }^{20}$

Denmark itself also took part in the blockade of Soviet Russia in 1918-1920, even if it was done secretly, without any legal base whatsoever, and without informing the Danish population of the blockade. ${ }^{21}$ Any sort of trade and communication with Soviet Russia was terminated, including postal communication.

Danish Volunteers

When the government of Kārlis Ulmanis was ousted from Riga by Soviet Russian and Latvian Bolsheviks at the end of 1918, the Latvian Prime Minister went from Liepāja to Denmark to ask for Danish assistance in order to get his government reinstalled in Riga. Ulmanis and his ministers of finance and agriculture were evacuated on board the steamship H. C. Ørsted, belonging to the Great Northern Telegraph Company. Ulmanis appealed to the Danish public and had talks with the leader of a private voluntary Danish military force. ${ }^{22}$

Great Britain supported the idea of Scandinavian volunteers to the Baltic states. In March 1919 the British Foreign Secretary expressed the hope that Danish volunteers soon would be able to fight the Bolshevik threat. A little later the first group of Danish volunteers (about 200) actually went off to Estonia. They were armed with the Danish machine guns already sold to the British in November 1918. Danish officers were not allowed to volunteer, as were their Swedish colleagues.

The recruiting and enlistment of Danish volunteers went on according to Danish law. Because of pressure on the government

${ }^{19}$ UM 147 E 4. UM to Danish embassy in Helsinki 28.12.1918; Marine ministry to UM 28.12.1918.

${ }^{20}$ Olavi Hovi. The Baltic Area in British Policy, 1918-1921. Helsinki, 1981, $82 \mathrm{ff}$.

${ }^{21}$ Bent Jensen. Danmark, $174 \mathrm{ff}$.

${ }^{22}$ Berlingske Tidende. 22.1. and 23.1.1919. American chargé d'affaires to State Department 24.1.1919, FRUS. Russia. 1919 (Washington 1937), p. 667. 
from the Social Democratic party, however, the government later prohibited recruiting. ${ }^{23}$

"Not able to recognize"

The question of recognition was raised once more at a Scandinavian summit in Stockholm in May 1919. There was agreement about the position that formal recognition of the new states in Eastern Europe could not be extended as long as the Peace Conference was going on in Paris. Even when the Peace Conference had concluded its work, 'the Russian Question' in all its aspects was left completely unsolved. When the Estonian diplomatic representative in Denmark, Karl Menning, asked for recognition in November 1919, he was told by the Danish Foreign Ministry that Denmark would keep up its already existing de facto relations with the Estonian Republic. 'For the time being', however, the Danish government was 'not able to recognize the Estonian Republic as an independent state'.

The Danish Foreign Ministry did not explain why Denmark was not able to extend recognition to Estonia. One reason was surely the very negative reports from Denmark's diplomatic representative in Estonia, Consul General J. Johansen, who warned about the impossibility of an independent Estonia. In his opinion there was 'neither the necessary economic basis, nor the necessary political maturity available.' In the summer of 1919 he told the Danish government that the future of Estonia must be based on 'relations with or control from other powers.' At the utmost Estonia should have autonomy under Russia.

A more influential factor, however, was that Estonia at that time had not been recognized by any state, neither had the policy of the Great Powers yet been defined. Much the same attitude was shown towards Latvia and Lithuania. Denmark had at precisely that time been forced by Great Britain to host the Bolshevik Vice Commissar for foreign affairs, Maksim Litvinov, formally dressed up as a representative of the Russian Red Cross. Litvinov also tried in vain to get formal Danish recognition of his government. In many respects, however, Litvinov's prolonged stay in Denmark from November 1919 till September 1920 became a breakthrough in the Bolshevik government's efforts to establish trade and diplomatic relations with Western Europe. ${ }^{24}$

\section{${ }^{23}$ Bent Jensen. Danmark, p. 204-207.}

${ }^{24}$ Bent Jensen. Kleinstaat in der Klemme. Dänemark als unfreiwilliges Gastland für einen bolschewistischen 'Weltgesandten'. Jahrbücher für Geschichte Osteuropas 38, 1990, 228-243. 
A third factor was the widespread belief that Russia sooner or later would be restored to its former size with the exclusion of Finland and Poland. The Russian Union in Denmark in a report from 1918 declared that a new Russia organized on a federative principle would reunite all the detached provinces (minus Poland but plus Finland), and that all the secondary nationalities' would get only local autonomy. ${ }^{25}$

\section{Normalization}

In January 1920 the Great Powers led by Great Britain decided to lift the blockade of Soviet Russia in order to resume trade with 'the Russian people' represented by the Russian Co-operative movement, Tsentrosoiuz. This scheme, however, was soon thwarted by the Bolshevik government which simply took over the Tsentrosoiuz. In the following months London was rather actively trying to normalize its relations with Moscow, but it was not until the spring of 1921 that a treaty of trade between the Soviet government and the British government was concluded. ${ }^{26}$

In the autumn of 1920 the Danish government once more made its negative position clear on the Baltic issue. At a summit meeting of cabinet ministers from the Scandinavian countries where the Russian Question was the central theme the Danish foreign minister, Harald Scavenius, openly declared that Denmark would only recognize the Baltic states if the Great Powers first extended their recognition, and preferably in a joint Scandinavian action together with Norway and Sweden.

By 'Great Powers' the Danish foreign minister had England and France in mind, not Bolshevik Russia, which at the time had concluded peace treaties with all three Baltic states and thus officially recognized their existence as independent states (Estonia 192002 02, Lithuania - 192007 12, and Latvia - 192008 11).

The 'Real Russia's' Need of its Baltic Ports

Harald Scavenius' argument for not recognizing the Baltic states was founded on his non-belief in the possibility of existence of these states in the long run. This was also the Swedish position at the time, and more importantly - it was also the French position. It was Harald Scavenius who had wanted the Russian Question as the main point on the agenda. The summer of 1920 had seen the Soviet military offensive in Poland. Now the Red Army was in retreat, but the Bolshevik regime was still in power. The Danish foreign minister was

${ }^{25}$ E. Bennigsen. Quelques chiffres concernant la question des nationalités en Russie. Copenhagen, 1918.

${ }^{26}$ Bent Jensen. Danmark, 299 ff. and 364. 
deeply convinced, however, that the Bolshevik system in Russia sooner or later would rot from within because it was based on principles against human nature.

When 'the real Russia' (by which he meant a non-Bolshevik Russia) was reestablished its first step would be to reconquer these territories, he said, because Russia was not able to exist without access to 'its' Baltic ports. There was, therefore, no reason to recognize the Baltic governments, all the more so because all Russians, whatever their political colour, would be much annoyed by Danish recognition. He added that two of the Baltic republics had not acted properly towards Denmark, having nationalized Danish property without compensation.

The Danish Prime Minister, Niels Neergaard, supported his foreign minister's view as to the necessity for Russia to have access to the Baltic Sea. In principle he also supported the right of nations to self-determination. For the time being, however, formal recognition was out of the question, he concluded. He thought a Russian confederation with the Baltic nations as members was a likely outcome. ${ }^{27}$

Denmark and the Vilnius Question of 1920

In November 1920 Denmark, Norway and Sweden (plus other countries) were asked by the League of Nations to supply 100 troops and four to five officers to take part in monitoring and securing a referendum concerning the Vilnius area. A few months before Allied troops had secured the referendum which reunited Northern Schleswig with Denmark. Nevertheless, reservations against Danish participation in the Vilnius referendum were voiced in the Danish government especially in the Social Democratic and the Radical Left parties. A law was eventually passed which stressed that only volunteers could be dispatched to the area, and that the task must only comprise police duties.

The referendum was never held because of Polish-Lithuanian disagreements, and the Danish force was dissolved in March 1921. The Danish government, however, wanted the League of Nations to pay for the costs of the formation of the Danish force, and actually got the money in $1923 .{ }^{28}$

When the Baltic states applied for membership of the League of Nations in 1920 Denmark and the two other Scandinavian governments voted against in December 1920. The Danish foreign minister had already explained Denmark's position in November when

${ }^{27} \mathrm{UM} 5 \mathrm{~F} 48 \mathrm{~b}$. Minutes of the Nordic meeting of Ministers 28-30.8.1920.

${ }^{28}$ Frederiksen. Danmark og de baltiske lande, 22-29. 
the Estonian representative in Copenhagen was told that the Danish government would not vote for League of Nations membership for states which were not recognized de jure. Harald Scavenius also referred to the need of small states like the Scandinavian to follow the Great Powers' attitude. ${ }^{29}$

Lithuania's recognition de jure

Soon, however, in January 1921, the Great Powers decided to recognize Estonia and Latvia de jure, and the Scandinavian governments immediately followed suit. Only a week after the Allied Supreme Council's decision Sweden recognized Estonia and Latvia de jure. The Danish foreign minister was dissatisfied with Sweden's hurry. He wanted the question discussed at a Scandinavian summit, but in order not to break the Scandinavian solidarity Denmark decided to follow Sweden. ${ }^{30}$

In 1921 an important Danish step was taken when Denmark established a consulate in Kaunas, the capital of Lithuania. Erik Biering, who before the Russian revolution had been active in Russia as a businessman, was appointed consul. ${ }^{31}$ By this step Denmark's de facto relations with Lithuania were strengthened and a Danish diplomatic mission could quickly be established if necessary.

Only in September 1921 was Lithuania recognized de jure by Denmark and the other Scandinavian states. The reason was once more the attitude of the Great Powers. In internal deliberation in the Danish Foreign Ministry in April 1921 attention was drawn to the fact that the Supreme Council of the Entente Powers was against recognition of Lithuania because of the unsolved Vilnius Question. Interestingly enough, in Septe- ${ }^{-} \cdot \circ$ r the same year an official in the foreign ministry argued that $\mathrm{t}$ ' $\mathrm{e} \mathrm{b}$ ' rder question was only used as an excuse for not recognizing Litnuania. He underlined the fact that Denmark had recognized other states with unstable borders, e.g., Poland. He was also of the opinion that the policy of the Great Powers should not determine the attitude of Denmark, pointing to the fact that Denmark also was a Baltic state. Because Lithuania was situated on the Baltic Sea the Scandinavian countries should take the lead in the question of recognition. ${ }^{32}$

${ }^{29}$ Kärlis Kangeris. Die schwedische Baltikumpolitik 1918-1925. Ein Überblick. Studia Baltica Stockholmiensia 3. 1988, 192.

${ }^{30}$ Ibid, 192-193; no. 17 , p. 203-204.

${ }^{31}$ Biering's immediate reaction when offered the post was: 'Kaunas, but this is a little old Russian fortress. What do you expect to do there?'

${ }^{32}$ UM 148 D 10. Minute of 27.4.1921 by G[ustav] R[asmussen]. 
The official did not explicitly say why a common position at the same sea should have any bearing on the question of recognition. But in some way he must have meant that recognition would be in Denmark's own political or economic interest. Maybe he thought on the same line as the Danish consul in Kaunas who also argued for Danish recognition. According to Biering, recognition would further Danish trade with Lithuania. Switzerland had extended recognition to Lithuania at the beginning of September 1921, and Swiss cattle competed with Danish cattle for export to the country. ${ }^{33}$

Apparently economic interests were the motive for Denmark to go ahead instead of waiting for the Great Powers to act. ${ }^{34} \mathrm{~A}$ week after the acceptance of Lithuania into the League of Nations, Denmark at last recognized the Lithuanian state de jure, while the Entente Powers waited until December 1922, and the United States extended formal recognition in August 1922.

\section{Conclusion}

The reaction of Denmark and the other Scandinavian countries to the declaration of independence of the Baltic nations, and the Scandinavian governments' policies as regards support and recognition of the new Baltic states were based on typically small state attitudes.

The First Commandment in the Small State Bible was never to take the initiative in questions where Great Power interests were at stake, but always follow the lead of the strongest power or combination of powers. Another essential principle was never to get directly militarily involved in areas of conflict or for that matter in any area. A third principle was not to get politically involved in schemes related to unstable states which were not seen as viable in the longer run.

In was economic self-interests and not a policy based on lofty principles building on the right of nations to self-dependence which determined Denmark's attitude to Lithuania and the two other Baltic states in the formative years of nation and state building.

It was the same viewpoint which governed Denmark's attitude right up to the liquidation of Lithuania, Latvia and Estonia in 1940.

${ }^{33}$ UM 148 D 10. Biering to UM 19.9.1921.

${ }^{34}$ UM 148 D 10. Harald Scavenius to Swedish Ambassador in Denmark 22.9.1921. 